\title{
The Archaeology of Earth
}

\section{Terje Gansum}

\begin{abstract}
"If we are to understand the concept and consequences of isolated burial mounds ... it is not enough to connect them with burial practice and social segregation. Something is missing" (Baudou 1989:17, my transl.).
\end{abstract}

\begin{abstract}
In this article, the author takes a closer look at mounds built of earth. The point of departure is that there is more to earth than building material. To pinpoint the view: earth is probably the main material for an archaeologist, not the artefacts. How do archaeologists treat earth? How is earth recorded when excavating, for instance, mounds? If we focus on the possibilities we may ask: what is the element earth connected to or associated with? What does earth mean in different contexts? The author does not pretend to have the right answers, but believes it is necessary to pose some questions.

Terje Gansum, National Heritage Board, UV Mitt, Instrumentvägen 19, SE-126 53 Hägersten, Sweden.
\end{abstract}

Key words: Mound, earth, excavation, metaphors, mother earth.

\section{LANDSCAPE AND MEMORIES}

Long and short histories can describe the mounds of earth, which we experience. The mounds are memories, built and left by others. As such they have a long history. The mounds were built to last, and the building of mounds has been carried out over long time spans in most of Europe. Many of the mounds are constructed according to plans, which must have involved heavy logistics and a lot of labour (Krogh 1993; Skre 1997; Jensen 1998; Gansum 2002a, 2002b). I will not go into a discussion of construction principles here, but instead concentrate on earth as a medium.

People have seen that the mounds lasted. They did not disappear. The mounds are exposed in the surroundings and create contrasts and differences in the topography (Gansum et al 1997). The human eye registers these kinds of contrasts. The mounds are noticed; they receive names; and they become memories, symbols and landmarks in the landscape (Welinder 1992; Tilley 1994). The content of meaning may or may not change, but the physical remains - the mound - may be 


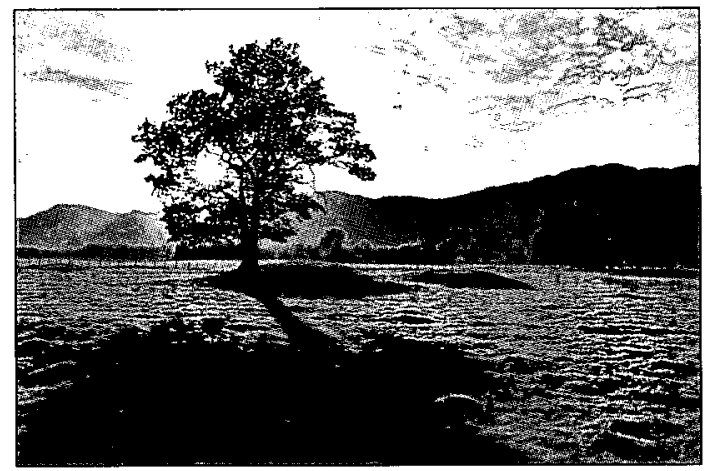

Fig. 1. Mounds in Etne, western Norway (Photo: Osterdal).

the same (Burström 1993, 1996). This brings us to a key point in preChristian culture in Scandinavia, namely, the meaning and honour connected to memory. Visibility, monumentality and exposure are connected to collective references.

Mounds maintain histories and reproduce narratives, and they are part of the understanding of time and a guarantee for memories. Memory is intimately connected to honour, which shall survive death ('Håvamál' stanza 76-77; Meulengracht-Sørensen 1995).

The mounds represent the long history, just as the rituals performed during the construction of the mounds and the reopening and inclusions may represent the short histories of a human lifetime. Openings and inclusions may be a material confirmation of mythical and ritual conceptions connected to the building of mounds. In this way, the short history of a human lifetime may be incorporated into the long history of the monument. The openings and inclusions can be seen as a confirmation of an ancestral sphere. The rituals may fill the production of memories and may vitalise the visual landscape, which implies a greater story than the single individual's. The long and the short history merge, and the mound may be the focal point where this takes place. The mound constructions are the visualisation of this process. But why did people choose to build their memories in earth?

In a farming society, soil/earth is the essential resource. Desirable resources such as soil, gold, flint or metal may be sacrificed. By building earth constructions, earth is visualised; at the same time the earth becomes dysfunctional in a modern, rational, farming perspective (Kristiansen 1986). Seen in a symbolic perspective, these constructions cover the necessary ritual behaviour by which humans sacrifice their most precious things or resources. Building a mound as a sacrifice may actually be a kind of investment; the mound builders invest by strengthening the gods in their common future. No such investment can be too big.

As archaeologists we often think of mounds as form and content, which is a parallel to the dichotomy of body and soul. This kind of thinking presupposes that people have seen earth as separate from content such as stones, charcoal, bones or artefacts. If there is such a distinction, it may be possible to view the content as having been carefully chosen and encapsulated (Goldhahn 1999, 2000). On the other hand, the dichotomy of body and soul, or form and content, is very influenced by Christian thinking, and we may get a totally anachronistic interpretation. Perhaps there is no distinction between form and content, where artefacts are part of the earth and become an ancestral sphere? Or is it possible to 
see earth as an active force that gives life to people and artefacts? Farming and harvesting represent the most obvious connection between people and earth (Rudebeck 2000), but are there other dimensions to earth?

\section{EARTH AS THE OPPOSITE ELEMENT}

The Greek philosophers debated the elements earth, fire, air and water in the period 550-400 BC. Thales from Miletus meant that the only sustainable element was water. Heraclitus argued for fire, while Anaximedes' solution to the problem was air (Amaldi 1966:17-18). None argued for earth! Earth was transformable, but was defined by departure from the other elements and was treated as an opposition and contrast. Thales argued that earth floats on water (Allen 1966:30). Thoughts of erosion, rain and rivers and the changes that accompany such processes may be some of the reasons that Heraclitus formulated the following:

Sea pours out (from earth), and it measures up to the same amount it was before becoming earth" (fragment XXXIX in Kahn 1993:69). An alternative interpretation of the text may be read like this: "Earth dissolves as sea, and it measures up to the same logos as was there at first" (Kahn 1993:69). The text is also translated in other words: "When earth has melted into sea, the resultant amount is the same as there had been before the sea became hardened into earth (Wheelwright 1959:37).

Earth is defined as opposition and contrast to air, but could also be seen as compressed water (Allen 1966:250). The Greek philosophers who were concerned with the elements were constantly seeking the dominating element, as well as the relations between the elements that could be explained with change and without loss: "and for this reason they consider that there is no absolute coming-to-be or passing away, of the ground that such a nature is always preserved" (Allen 1966:30).

The thought that earth does not disappear but is merely displaced and moved is a perspective I will discuss below (Lucas 2001b). In an archaeological and technological perspective, the knowledge and use of earth, fire, air and water are a lot older than the philosophers themselves. In the production of iron all elements are part of the technology. A philosopher such as Thales was a well-educated man; as an engineer, he had craftsmanship and skills in practical work, and he was a strategist and philosopher. In books on philosophy these practical skills, technologies and knowledge that are connected to activities are mostly treated as irrelevant to the subject (Wittgenstein 2003). In contrast, I would argue that it is partly this skill that gives substance to the thinking.

As archaeologists we have to deal with the past by moving earth. This is a practical and philosophical labour. There are several decisions concerning excavation technique, documentation or excavating strategies. How do archaeologists treat earth? 


\section{AN ARCHAEOLOGICAL PRACTICE}

Archaeologists (re)move earth, but is this process connected to thoughts of earth as the key source of information on past decision making? What do archaeologists record, and what is left without being recorded? Is earth judged to be a mere container for artefacts, or is there more to find out in the excavation process?

Earth is probably the main material for most excavating archaeologists, but it is also probably the material that receives a minimum of brainwork in the excavation report, at least when dealing with mounds. It all ends up as a description linked to a cross-section (Ramqvist 1992; Gansum 1995). Archaeology was influenced by geology in the 1830s and some 40 years onwards (Larsson 2000; Gansum forthcoming). The geologists tried to analyse stratigraphy in order to explain and understand the deposition processes. But as the study of archaeology developed inside museums through the study of artefacts, the influence of geology faded. The real archaeology was not defined by fieldwork. Fieldwork was just the proper way to find artefacts. This harsh summery is, of course, not just, but it pinpoints that geology and stratigraphy were not part of the archaeological debate until the early 1960s with the New Archaeology (Ratje \& Schiffer 1980). This approach was developed further in urban archaeology in the 1970s (Harris 1989; Anund 1995). Each culturally influenced stratum or context may be connected to human actions. By applying stratigraphic excavation and documentation, the archaeologist may try to find out the sequence of actions and use that is a guide to meaning and explanation. This approach makes earth the essential source material in the excavating process.

By applying single-context planning, the archaeologist can document depositions and sequences that are part of actions conducted at the site. Deposition history is probably the archaeological future. Each context may be connected to actions of different temporality, but by recording every positive or negative stratigraphic unit we may understand more about the mounds than we can by studying cross-sections. The interfaces are among the most important features to understand in order to discern the kind of actions that took place. Actions and social praxis take place on top of the soil, not inside a layer (Larsson 2000:102).

The interfaces that have been ex-

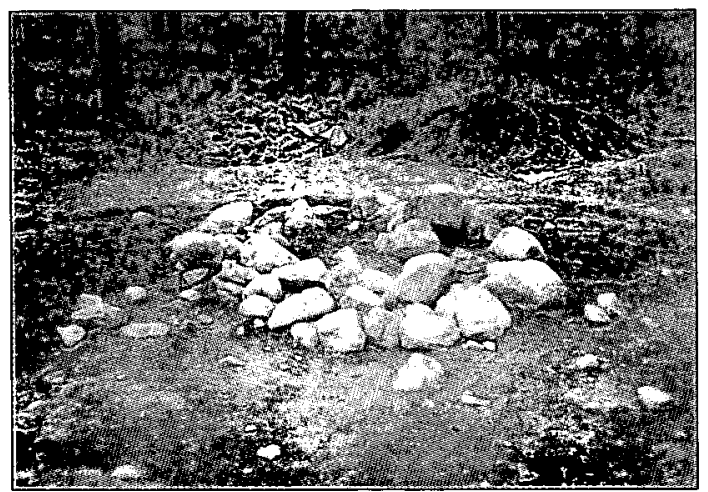
posed for a long time period will be keys to understanding the mound constructions as well (Krogh 1993:98, 222; Holst et al 2001). The stratigraphy recorded in a matrix gives other possibilities to tell more complex stories, also with

Fig. 2. Excavation of a mound at Vårby 2003. Turf and earth are moved into a new context as heaps (Photo: Gansum). 


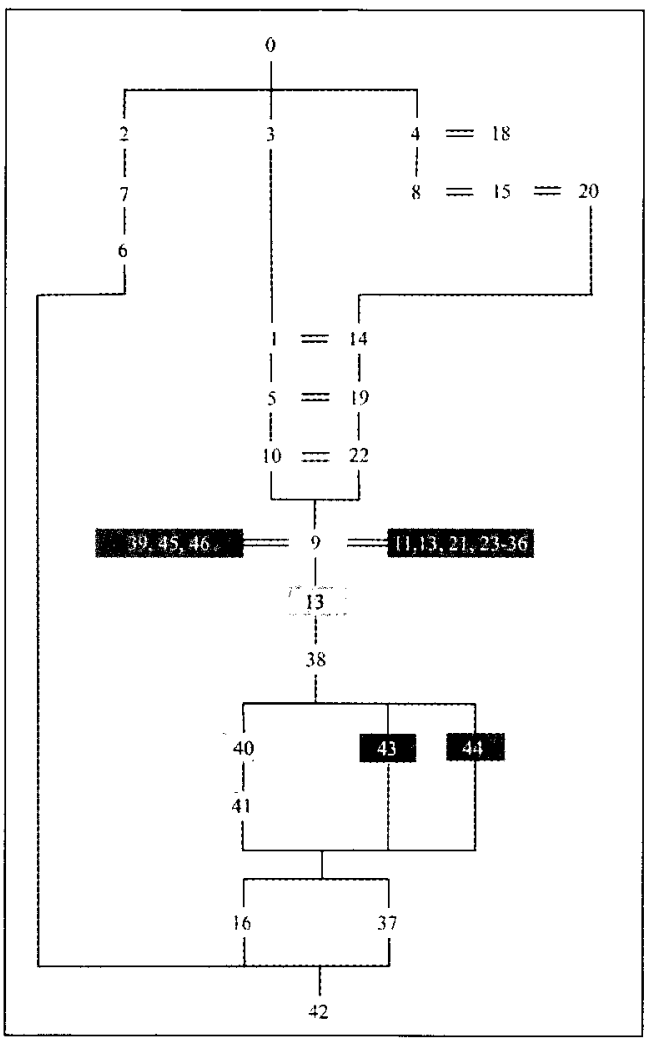

Fig. 3. The stratigraphic matrix of the mound at $V$ airby shows relations between different contexts and is a guide to interpreting deposits in the mound construction. The matrix is by no means a goal in itself, but is an interpretation that needs more elaboration regarding meaning, i.e. finds, dating techniques.

regard to the mounds, which all too often are interpreted in an overly simplistic way.

Single-context planning makes it possible to trace contexts down to great detail through analyses of soil, macrofossils, ${ }^{14} \mathrm{C}$, artefacts, etc. There are economic limits that put the breaks on analysis, but to pinpoint my view again: I don't believe that the important answers are found in the machinery or laboratories. We need a cultural humanistic perspective on earth to understand the past use of it. The archaeological approach should be developed through greater concern in our fieldwork and documentation practice (Lucas 2001a). If excavations of mounds are to improve, we need to change some traditions concerning excavation and documentation techniques. This may be done with different excavation strategies (Holst et al 2001; Holst \& Rasmussen 2002; Gansum 2002a).

\section{MOVING AND REMOVING EARTH}

A constructive approach to the transportation of earth has been given and discussed by Gavin Lucas (Lucas 2001a, 2001b). Lucas' change of focus directs the reader's mind to the fact that earth does not disappear (i.e., Greek philosophers). Earth is displaced and steadily given new contexts. This may take on different expressions. In an urban site there are numerous displacements and transformations (Larsson 1993:45-46; Olsson 1999). In burial-grounds or cemeteries there are many forms of displacements and transformations. Mounds may have traces of earlier excavations, and these are often interpreted as the result of robbery or rituals where people removed artefacts and skeletons from the mound (Brøgger 1945). This activity is seldom studied, and single-context planning may be a useful approach to these ritual constructions. Mounds consist of earth, which is ritually deposited. Mounds may superimpose other constructions, and that may cause archaeologists to use words describing destruction. The reopening of mounds is often described 
as robbery. The preservation of monuments or sites without archaeological interference seems to be the main goal:

Cultural Resource Management (CRM) strategies which promote this kind of thinking clearly set up the concept of preservation as distinct from this notion of destruction. Indeed, to some extent this is the inevitable logic of this paradox, where preservation is the ideal, the preferred option in heritage management (Lucas 2001b:37).

The rhetoric departing from the concept that the archaeological record is a kind of resource, is not achieving the needed work for the renewal of archaeological thinking. The trouble lies in the language, especially in the notions of destruction/ preservation, which block any form of creative discussion.

The metaphor [resource] is continued through associated terms such as "finite", "non-renewable" and "sustainable". Indeed, by characterizing the archaeological record as a resource, as something which is either destroyed or preserved, independent of any intellectual evaluation we place over this resource, we encourage a view of the past as separate from the present and future, more significantly as something static, dead. In viewing the archaeological record as a resource, it is as if it were a commodity or raw material involved in a process of production - in this case, the production of knowledge (Lucas 2001b:37).

Lucas points out and criticises the binary notions of destruction/preservation and the rhetoric that uses resource as metaphor. His argument is directed at the cultural management that sustains the limit between subject (the archaeologist) and object (the material reality). The question we may consider is whether the distinction of objective (the material reality) is relevant to sustain, if the existence as archaeological material is fully dependent on our characterising of it as such (Lucas $2001 \mathrm{~b}: 38$ ). This highlights the choices we make when excavating. "It is a pit because we dig it/record it like a pit" (Lucas 2001b:45). Or to put it in other words:

Moreover, one might almost say that we dug it in this way because of the way we were going to draw it - in which case, which is metaphor and which is the referent? (Lucas 2001b:45).

The choices we make show that the material reality (objective) in no way can be separated from our subjective experiences and skills evolved through fieldwork. Standardization through manuals, lists, digital categorization, etc. does not secure more objectivity. The result is standardization and comparability. If we look at this practice in a structural power perspective, it is obvious that this approach secures likeness on behalf of experience and a site's particular history. Lucas is by no means a nihilistic relativist; he looks for ways out by introducing the notions of "displacement" and "transformation". An archaeological excavation should 
be seen as a process whereby earth is interpreted and moved from one context to another. The earth does not disappear, but is moved. Instead of seeing fieldwork as a question of conservation or destruction, it is better to treat this as a hermeneutic process involving transformation and displacement (Lucas 2001b:40).

These notions may be useful when dealing with mounds, the reopening of them and the fact that many of these constructions have changed radically several times in the past (Gansum 2002a). If this approach is taken seriously, we have to realise that earth is both the medium and the goal if we want to explain actions and the history of deposition.

\section{EARTH IS MORE THAN CONSTRUCTION MATERIAL}

Earth is an imprecise notion and is in an indefinite form. This may actually be useful when we treat this subject and do not want to get lost in details. Details will become a necessary part of the subject when we consider excavations and fieldwork, that is, the archaeological praxis. The fact that mounds consist of earth should be analysed in greater detail.

In numerous excavations of mounds the combinations of earth/soils is by no means random. In Bronze Age mounds, Danish archaeologists have been able to detect construction principles which indicate a complex operation that depends on skills in logistics and that different people had responsibility for various parts of the construction (http:www.skelhoej.natmus.dk). The forthcoming analyses from this project will be delivered by disciplines such as pedology, geology and chemistry. This kind of cooperation is much needed. However, this cooperation must not lead archaeologists to believe that they can lean back and do the same old stuff. There is much to be done regarding excavation techniques and documentation routines if we want to develop archaeology (Holst \& Rasmussen 2002; Gansum 2002a). Interpretations of earth are in my opinion necessary, and in the following I will give some examples.

Observations of the composition of sand and soil may also add to our knowledge about the past. In coffins of stone from the Early Bronze Age, there is documented sand containing shells and snails that are found at the shore. The sea was, so to speak, brought into the coffin in the form of sand and small stones (Larsen 1996:52). There are lot of examples that show that this phenomenon is not random. There is a link between the shore and the coffin: The limit between water and land, between life and death, and between earth, stone and water. The elements are metaphors that are interlinked by associations (Gansum 1999, 2003).

Earth is not a neutral element in societies that subsist on a farming economy. The earth is cultivated, and through cultivation humans connect to earth with technology, symbols and rituals, which constantly change in respect to the symbolic meaning. In mythology and folklore there are symbolic and ritual relations to the cultivated earth (Kaliff \& Östegård this volume). The cultivation may be seen in connection with fertility rituals, with metaphors associated with breeding and deliveries (Steinsland \& Meulengracht-Sørensen 1994). In pre- 
Christian Scandinavia the earth was seen as a woman, and as such as a mistress, as a womb, as a furnace and part of the family possessions. The "Odal earth" showed rights and displayed duties (Zachrisson 1994). The perspective on Eros and fertility in pre-Christian Scandinavia is intimately connected to death, which is not a contrast or in any sense an opposition to fertility, but mainly can be seen as a precaution and duration for the continuum of life on earth (Bloch \& Parry 1989:7-8; Steinsland 1997). The ancestral and the living were connected to and through earth, symbolised by mounds. The ancestral was visible in the landscape, and the mounds were also intimately connected to jurisdiction. It is therefore not surprising that mounds were sites for rituals, and a place to worship and cultivate the dead (Birkeli 1938; Brendalsmo \& Røthe 1992; Randsborg 1998). The interpretation of written sources that speak of earth is often based on functional aspects. The reading and understanding of the treatment of earth in The Poetic Edda is not a straightforward task. It is therefore my hope that the archaeology of earth may shed some light on rituals and cult in pre-Christian Scandinavia. In 'Voluspá' stanza 10, dwarfs create humans from earth. I will now take a closer look at the phenomenon of the fertile mother earth. What is she delivering?

\section{EARTH AND IRON - SEXUAL CONNOTATIONS}

If we start out with a practical point of view, we know that people collected earth from the moors and dried it before burning the turf. The earth went through a refining process whereby the organic content was removed. The earth was transformed. The furnace was built of clay, and sometimes stones were added. In all parts of the process, earth was a main factor.

In studies by ethnoarchaeologists and anthropologists there is a substantial body of evidence that supports the idea of the production of iron as ritualised and regulated by taboos (Rijal 1998; Englund 1999, 2002; Barndon 1996, 2001a; Haaland et al 2002). Many of the taboos and ritual performances link up with ideology and religion (Anfinset 1999:19). It is possible that people in Iron Age Scandinavia did have much of the same ritual actions, since the technology basically was the same. I will now try to link rituals, technology and religious belief by using The Poetic Edda. My point of departure is based on the conviction that people in pre-Christian Scandinavia did not separate actions, thoughts and technique; they were all interlinked in cosmology and revealed by rituals, which gave meaning to the material world.

Studies of traditional societies that produce iron often report that the production is strictly regulated by sexual taboos and ritual behaviour. Randi Barndon has documented the sexual connotations concerning iron production in detail (1996, 2001a, 2001b). The furnace may have female attributes such as breasts or openings shaped as vulvas, including legs lying on the ground (Barndon 2001b; Englund 1999:107-108). Sexual taboos are reported and described by several researchers, and we can cite Rijal's work on iron production in Nepal: 


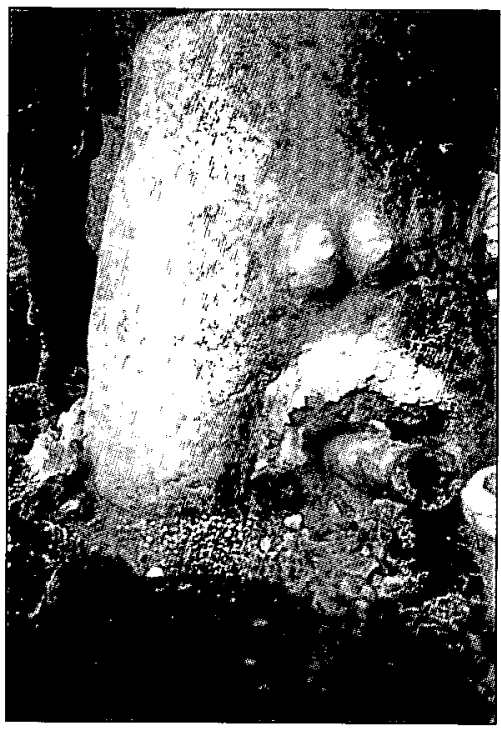

Fig. 4. Furnace with breast and vulva penetrated (Photo: Barndon).

"The concepts of "fertility" and "sex" involved in smelting are also evident in the speech and actions of the miners. No one is allowed to watch when the smelter is placing the tuyeres into the furnace. The smelter while doing so has to be totally naked in front of the furnace. This is another example, which illustrates the representation of the furnace as the smelter's wife - his nakedness illustrating the intimacy between the husband and wife. The tuyeres, which have phallic appearances, are known as "tora", which is just a slight modification of the Nepali term for male genitalia, which is "turi". The pumping of the bellows is regarded as the "heavy breathing during sexual intercourse". Among the Agaria of India, there is a saying that "the woman gives birth and the man cares for it", which means the iron that was born in the furnace must be refined in the forge" (Rijal 1998:73).

The furnace represents the bride preparing for a wedding, and she goes through initiation rites like a girl preparing for the social classification of woman. She is prepared for the meeting with the bridegroom. The sound of the bellows, the heated furnace and delivery of a lump of iron include elements that may lead thoughts to sexual actions and birth. The furnaces in the Scandinavian material are poorly preserved above ground level. We are forced to draw analogies, which may lead to uncertain conclusions. Many studies of traditional iron production in Africa or Asia seem to show much of the technique in common with the Iron Age material from Scandinavia. It is possible that the production of iron in Scandinavia may be associated with sexuality.

A consequence of the birth of iron may lead us to treat the artefacts as having social qualities and names, which indeed they have. The mythology is probably telling about the birth of iron.

Fig. 5. Furnace at Borre with bellows (Photo: Gansum).

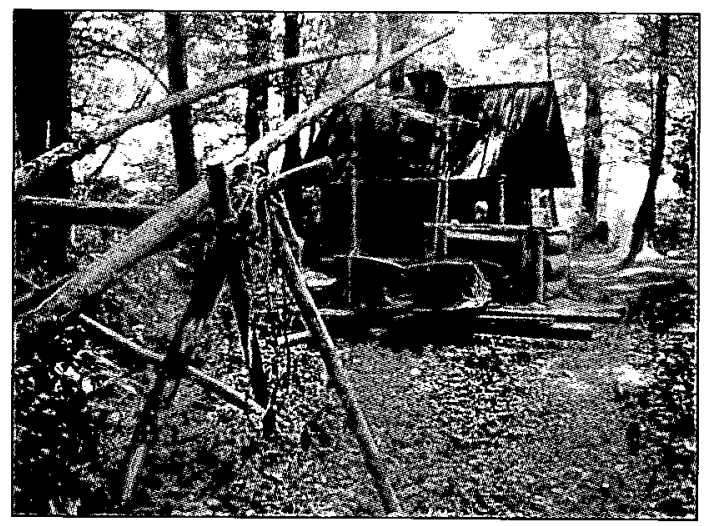




\section{MOTHER EARTH}

In this short presentation I will take a closer look at the role earth plays in the birth of iron. In the Norse pantheon earth is a giantess, and she plays an important role in the iron production. To support my interpretations I shall take a closer look at one stanza from The Poetic Edda poem 'Voluspá', where iron and earth are important elements for the understanding of the text. I want to draw attention to research where craftsmanship and scientific approaches are combined. The point of departure is 'Voluspá' stanza 40 (in the English version stanza 39). The narrative is built up towards Ragnarlk, when the world will go under and the wolf Fenris will kill Odin. In stanza 40 the offspring of Fenris are mentioned and they are given birth by an old giantess in a place called Járnviði, that is, the iron woods.

\section{Voluspá 40}

I øst satt den gamle

i Jernskogen

og fødte der

Fenres avkom;

av dem alle blir

én eneste

soltyggeren,

i trolleham

(Steinsland \&

Meulengracht-

Sørensen 1999:21)
Voluspá 39

Austr sat in aldna

i Járnviði

ok fæddi par

Fenris kindir;

verðr af peim öllum

einna nökkurr

tungls tjúgari

$i$ trolls hami

(Bugge 1965:7)
In the east she sat, the old one, in Iron Wood,

and bred there

the broods of Fenrir.

There will come from them all one of that number

to be a moon-snatcher

in troll's skin

(Dronke 1997:17)

The meaning of Járnvið is clear and cannot be interpreted in any other way. Fritzner points out several semantic meanings of the postfix viðr: a standing tree, a timber leg, mast, woods, or wood as a material (Fritzner 1896:932-933). Heggestad adds the side of a ship, or ship, but notes that vidr is known as a dwarf's name (Heggstad 1958:799). Viði is also known as a place-name, woodlands, in the poem 'Grimnesmál' 17, and as the postfix in the name Tyrving. If we take a closer look, vingr comes from the word vigg, which means horse, but it also refers to veigr, which is the name of another dwarf (Heggstad 1958:786, 802, 808; Steinsland \& Meulengracht-Sørensen 1999:111). The relations between mythology and iron production lead us in the direction of the smithy where horses, dwarf's names and transformations occur (Oma 2000). It seems as if there is a close connection between the production of iron and wood in the mythology as well as technology.

But there is more to this stanza of 'Voluspa' than meets the eye. The old one, the giantess who gives birth to Fenris' offspring, is not a biological creature. Old women can't give birth, but that is exactly what happens in the myth. The giantess has to be a metaphor. I suggest that the giantess is the earth, here built as a 


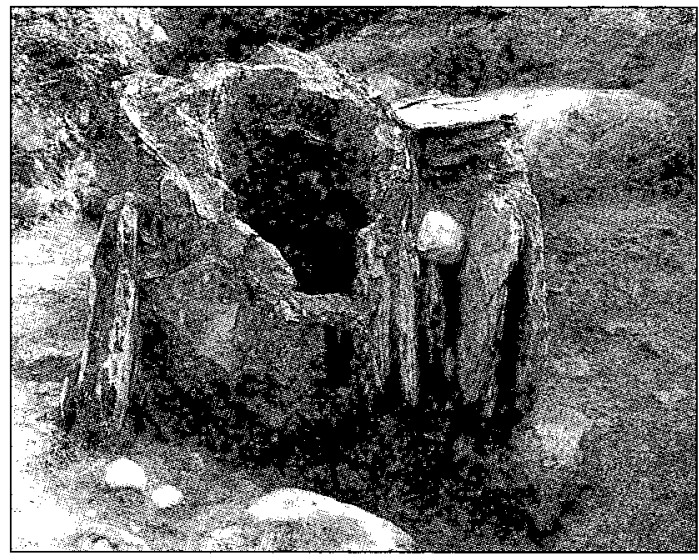

Fig. 6. Excavated furnace from the Late Iron Age at Dokfløy (Photo: Larsen).

smelting furnace. This smelting furnace may be old and still give birth. What, who or whom is hidden behind the kenning Fenris' offspring? Literally, Fenris' offspring refers to "wolves", but that is simply a logical interpretation, since Fenris is a wolf (Mundal $2002: 185)$. My suggestion is that iron and steel - i.e., weapons - are

Fenris' offspring, who in aldna gives birth to or is feeding, or both, similar to iron and arms (Surt from south in stanza 52). The poem 'Voluspá' builds up toward RagnarÍk in stanza 40, and what would be more appropriate than weapons? To conclude, I believe that it is the birth of iron and steel that takes place in this stanza. The one who devours the sun/moon is the furnace/forge where the smith works. And a shining weapon, used in the final battle, is the one in troll's skin (shining and brilliant i.e. steel). In 'Alvismál', "Dvalins leica" is the name of the sun, but it can also indicate a trap or betrayal, which will be a crucial point in my treatment of swords (Bugge 1965:131; Mortensson-Egnund 1974:77; Motz 1993:83 note 3).

Dwarfs function in and through technologies, things and actions. They were born before the humans, and we know of over 60 dwarf's names in 'Voluspá'. Dwarfs and horses are connected to the sun. The horses Rimfakse and Skinfakse pull the sun, and under the shoulders the asir-gods placed wind bellows, hidden powers and iron keels ('Grimnesmál' 37; Bugge 1965:84; Holm-Olsen 1993:51; Sturlasson $1967: 28)$. It is all very remindful of the activities in the smithy.

We must view them [dwarfs] as the mythical representatives of a profession, paralleling the craftmensmiths of early society, who were, indeed, endowed with ritual importance (Motz 1993:84).

Fig. 7. The birth of iron at Borre (Photo: Riverud, designed by Løwe design).

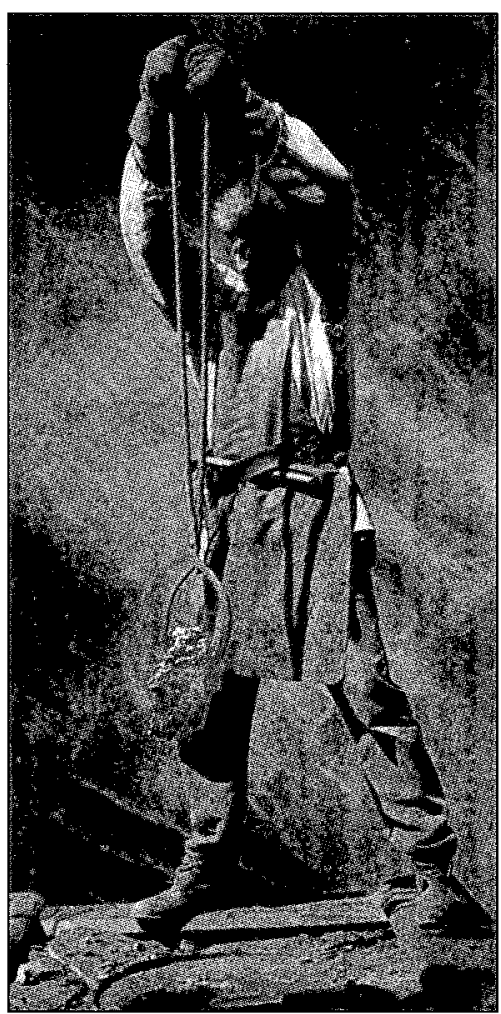




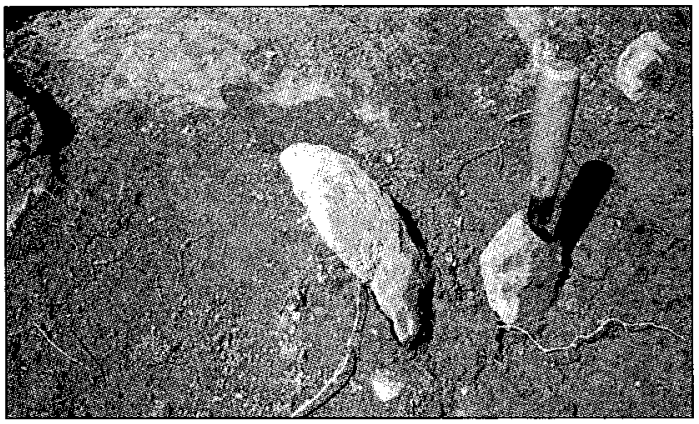

Fig. 8. Excavation of a mound at Vårby 2003.

The stone is recorded standing within a layer and indicate that the deposition of earth has gone fast. The archaeological experience must be discussed and developed as archaeology, and not only through other disciplines as part of "non-destructive" prospecting methods. We need to develop both, and not let technique become the great archaeological sleeping pillow (Photo: Gansum).

Earth could also unite or create family-like relations. In 'Gisli's Surssons saga', Torgrim, Gisle, Torkjell and Vestein mix blood and earth and crawl under turf in a ritual ceremony, which made them brothers ('Gisli's Surssons saga' chapter 6). It is obvious that earth as an element was connected to cosmology and rituals. In excavation reports there are sometimes revised close relations between furnaces and graves since graves are documented inside furnaces (Appelgren \& Broberg 1998:34-35). Birth and rebirth, death and fertility are discussed in anthropological literature and show us that perspectives on these subjects are closely interlinked in their way of thinking (Bloch \& Parry 1989). The relation between iron and earth is noted in literature (Burström 1990), but seldom treated in a symbolic perspective (Hjärtner-Holdar 1993; Englund 2002).

To sum up: the mythical version told in 'Voluspá' may be that earth gave birth to iron; and that the furnace was treated as a giantess / womb. The dwarfs gave the metal a soul and a life of its own, just as with the swords - Tyrving, Hrunting, Gråsida, Kvernbitt, Gram, Fetbrei, Bastard, Skrep and many more (Gansum \& Hansen 2002). Most of the swords are produced or kept under earth. There seem to be structural traits to these swords. They are kept under ground, in earth, and spells, betrayal and murder follow the swords. Odin has a central role in all the stories. The Odin's heiti gives us clues in this direction, and some of them are clearly derived from names describing the sword; Hött, Hjalti and Od are three examples of this (Näsström 2002:74).

\section{CONCLUSIONS}

Earth may be considered as a main source in archaeology even before analyses conducted by other scientists. My main goal has been to draw attention to depositions, interphases documented in stratigraphy, which shift the focus from artefacts to earth. The complex combination of depositions and removal of earth in a construction such as a mound is a great challenge to document. It takes more than a couple of cross-sections to grasp the complexity. During archaeological excavation we ought to consider earth as more than a container for artefacts. Perhaps most of the actions that we are able to discern from an investigation are connected to combinations of deposits consisting of earth with inclusions of things we define as content. We need to analyse contexts where earth makes a difference, 
and look for symbolism and associations that can explain the past ritual actions we are able to trace.

English revised by Laura Wrang.

\section{REFERENCES}

Allen, R. E. (Ed). 1966. Greek Philosophy: Thaless to Aristotle. The Free Press. New York.

Amaldi, G. 1966. The Nature of Matter: Physical Theory from Thaless to Fermi. The University of Chicago Press. Chicago.

Anfinset, N. 1999: Teknologi og etnoarkeologi. Viking LXII. Pp. 19-30.

Anund, J. 1995. Stadsarkeologi på UV Uppsala. Stratigrafisk metodhistorik och lägesrapport. META 2. Pp. 3-18.

Appelgren, K. \& Broberg, A. 1998. Gravar och ungar vid Gavleån. UV Stockholm Rapport 1996:130. Riksantikvarieämbetet. Gotarc. Series B. Gothenburg archaeological theses 15.

Barndon, R. 1996. Fipa Ironworking and Its Technological Style. In: Schmidt, P. (Ed). The Culture and Technology of Iron Production in Africa. Gainsville, University Press of Florida.

- 2001 a. Masters of Metallurgy - Masters of Metaphors. Iron working among the Fipa and the Pangwa of SW-Tanzania. Department of Archaeology, University of Bergen.

- 2001b. Jernteknologi og kjønnssymbolikk hos Fipa og Pangwa i sørvest-Tanzania. In Ådland, E. og Bang, K. (Eds). Kjonn, erotikk, religion. Bergen Museums Skrifter, vol 9, Bergen: Bergen Museum.

Baudou, E. 1989. Hög - gård - helgedom i Mellannorrland under äldre järnåldern. Arkeologi i Norr. 2. Pp. 9-44. Umeå.

Birkeli, E. 1938. Fedrekult i Norge. Et forsøk på en systematisk-deskreptiv fremstilling. Skrifter utgitt av det Norske Videnskaps-Akademi i Oslo. Hist.-Filos. Klasse No 5. Oslo.

Bloch, M. \& Parry, J. 1989. Death \& the Regeneration of Life. Cambridge University Press.

Brendalsmo, A.J. \& Røthe, G. 1992. Haugbrott eller de levendes forhold til de døde - en komparativ analyse. Meta 1-2. Pp. 84-119.

Brøgger, A.W. 1945. Oseberggraven - Haugbrott. Viking 9. Pp. 1-44. Oslo.

Bugge, S. 1965. Norrcen fornkvceði. Islandsk samling af folkelige oldtidsdigte om Nordens guder og heroer almindelig kaldet Samundar Edda hins fróða. Universitetsforlaget, Oslo.

Burström, M. 1993. Mångtydiga fornlämningar. SAR NR 27. Stockholm.

- 1996. Historier kring en hög. Mellan bronssköld och JAS-plan-glimtar av Lidköpingsbygens historia. Pp. 78-92. Lidköping.

Dronke, U. 1997. The Poetic Edda. Volume II. Mythological Poems. Claredon Press, Oxford.

Englund, L-E. 1999. Havandeskap och järnframställning. In Caesar, C. et al. (Ed). Han hon den det. Att integrera genus och kön i arkeologi. Repport series No. 65, Lund.

- 2002. Blästbruk. Jernkontorets Berghistoriska Skriftserie nr 40. Stockholm University.

Fritzner, J. 1896. Ordbog over Det gamle norske Sprog. Tredie Bind, R-Ö. Kristiania.

Gansum, T. Jerpåsen, G. \& Keller, C. 1997. Arkeologisk landskapsanalyse med visuelle metoder. AmSVaria 28.

Gansum, T. \& Hansen, H. J. 2002. Fra jern til stål. Mytologiske og rituelle aspekter i teknologiske prosesser. Midgard historisk senter, Borre.

Gansum, T. 1995: Haugar og Haugating. Rikssamlingen og det eldste Tonsberg. Forlaget Media, Tønsberg. - 1999. Mythos, logos, ritus. Symbolisme og gravskikk i lys av gudediktene i den eldre Edda. In: Fuglestvedt, I, \& Gansum, T \& Opedal, A. (Eds). Et hus med mange rom. Vennebok til Bjørn Myhre på 60-årsdagen. AmS-rapport 11. Bind B. Pp. 439-503. Arkeologisk museum i Stavanger. 
- 2002a. Fra jord til handling. In: Jennbert, K. Andrén, A. \& Raudvere, C. (Eds). Plats och praxis. Arkeologiska och religionshistoriska studier av norrön ritual. Vägar till Midgård 2. Pp. 249-286. Lund: Nordic Academic Press.

$-2002 b$. Oseberg $\S 2$. The Place $\S 3$. Construction of the mound. Reallexikon der Germanichen Altertumskunde. HOOPS Band 22. Pp. 306-309. Berlin, New York

- 2003. Hår og stil og stilig hår. Om langhåret maktsymbolikk. In: Stylegar, F-A. \& Rolfsen, P. (Eds).

Snartemoseminaret. Oldsaksamlingens skrifter. Pp. 191-220. Oslo.

- forthcoming. Hauger som konstruksjoner, Riksantikvarieämbetet.

Gisle Surssons saga 1985. I gjendiktning og oversettelse, med innledning, noter og essay ved Vera Henriksen. Aschehoug \& Co. Oslo.

Goldhahn, J. 1999. Sagaholm. Hällristningar och gravritual. Studia Archaeologica Universitatis Umensis 11.

- 2000. Hällristningar, kosmologi och begravningsritual - exempelet Sagaholm. Primitive tider: Pp. 19-50. Oslo.

Grimnesmál 1965. se Bugge, S. 1965.

Heggstad, L. 1958. Gamalnorsk ordbok. Med nynorsk tyding. Det norske Samlaget. Oslo.

Hjärthner-Holdar, E., 1987. Indikationer på tidig järnhandtering i Sverige. In: Tiiu, A., Hasselmo, M. \& Lamm, K. (Eds). 7000 år på 20 år. Pp. 109-130. Riksantikvarieämbetet.

- 1993. Järnets och järnmetallurgins introduktion $i$ Sverige. AUN 16.Uppsala.

Holm-Olsen, L. 1993. Edda-dikt. 2. reviderte opplag, Cappelens forlag A.S., Oslo.

Holst, M. K., Breuning-Madsen, H. \& Rasmussen, M. 2001. The South Scandinavian barrows with wellpreserved oak-log coffins. Antiquity, vol 75, nr. 287. Pp. 126-136.

Holst, M. K. \& Rasmussen, M. 2002. Præsentation af Skelhøjprojektet. Rapport datert Påske 2002. http $/$ /www.skelhoej.natmus.dk

Haaland, G., Haaland, R., Rijal, S. 2002. The Social Life of Iron. A Cross-Cultural Study of Technological, Symbolic, and Social Aspects of Iron Making. Anthropos 97. Pp. 35-54.

Håvamål 1965. se Bugge, S. 1965.

Jensen, J. 1998. Manden i kisten: hvad bronzealderens gravhøje gemte. Gyldendal, København.

Kahn, C. H. 1993. The Art and Thought of Heraclitus. Cambridge University Press.

Kaliff, A. \& Ostegård, T., this volume. Cultivating Corpses - A Comparative Approach to Disembodied Mortuary Remains. CSA.

Kristiansen, K. 1986. Ideologi och samfunn i Danmarks Bronzealder. Varia 12. Pp. 144-55. Oslo.

Krogh, K. J. 1993. Gåden om Kong Gorms grav: historien om Nordhøjen i Jelling. Carlsbergfondet og Nationalmuseet.

Larsen, I. C. 1996. Haugene fra eldre bronselader på Jæren - en religonsarkeologisk analyse. Upublisert hovedoppgave. Arkeologisk institutt. Universitetet i Bergen.

Larsson, S. 1993. Lunda-arkeologin i ljuset av erfarenheterna från de senaste utgrävningarna. META 3-4. Pp. 39-65.

-2000. Stadens dolda kulturskikt. Lundaarkeologins förutsettningar och förståelsehorisonter uttryckt genom praxis för källmaterialsproduktion 1890-1990. Archaeologica Lundensia IX.

Lucas, G. 2001 a. Critical Approaches to Fieldwork. Routledge London.

- 2001b. Destruction and the rhetoric of excavation. NAR, Vol 34, nr 1, Pp. 35-46.

Meulengracht Sørensen, P. 1995. Fortclling og cere. Studier $i$ islcendingesagaerne. Universitetsforlaget. Oslo.

Mortensson-Egnund, I. 1974. Edda-kvede. Det Norske Samlaget, Oslo.

Motz, L. 1993. The host of Dvalinn. Thoughts on Some Dwarf-names in Old Icelandic. Collegium Medievale 1. Pp. 81-96.

Mundal, E. 2002. Austr sat in aldna. Giantess and female powers in Víluspá. In Smiek, R. \& Heizmann, W. (Eds). Mythological Woman. Studies in Memory of Lotte Motz. Fassbaender - Wien.

Näsström, B.M. 2002. I livets skeden. Om passageriter i fornskandinavisk religion. In: Jennbert, K. Andrén, A. \& Raudvere, C. (Eds). Plats och praxis Arkeologiska och religionshistoriska studier av norrön ritual. Vägar till Midgård 2. Pp. 69-86. Nordic Academic Press. Lund. 
Olsson, A. 1999. Spår av avfallshandtering i ett medeltida urbant sammanhang. META 1, 49-65.

Oma, K. 2000. Hesten i nordisk jernalder: ei kontekstuell analyse av den symbolske sfære kontra den materielle røynda. Upublisert hovedfagsoppgave, IAKK, Universitetet i Oslo.

Randsborg, K. 1998. Plundered Bronze Age Graves. Archaeological and social implications. Acta Archaeologica 69. Pp. 113-38.

Ramqvist, P.H. 1992. Högom part 1. Archaeology and Environment 13 University of Umeå.

Rathje, W. L. \& Schiffer, M. B. 1980. Archaeology. Harcourt Brace Jovanovich Publishers.

Rijal, S. 1998. The Traditional System of Iron Working: Technology, Social Context and Rituals of Transformation. An Ethnoarchaeological Study from Eastern Nepal. Unpublished M. Phil. Thesis. University of Bergen.

Rudebeck, E. 2000. Tilling Nature Harvesting Culture. ACTA Archaeologica Lundensia. Series in $8^{\circ}$, No.32.

Skre. D. 1997. Raknehaugen. En empirisk loftsrydding. Viking LX. Pp. 7-42. Oslo.

Steinsland, G. \& Meulengracht Sørensen, P. 1994. Mennesker og makter $i$ vikingenes verden. Universitetsforlaget. Oslo.

- 1999. Voluspå. Pax Forlag A/S. Oslo.

Steinsland, G. 1997. Eros og dod i norrone myter. Universitetsforlaget. Oslo.

Sturlason, S. 1967. Den yngre Edda. Det Norske Samlaget. Oslo.

Tilley, C. 1994. A phenomenology of landscape. Berg Publishers. USA.

Welinder, S. 1992. Människor och landskap. Aun 15. Uppsala.

Wittgenstein, L. 2003. Filosofiske undersøkelser. Bokklubbens kulturbibliotek. De norske bokklubbene. Oslo.

Zachrisson, T. 1994. The Odal and its Manifestation in the Landscape. Current Swedish Archaeology, Vol. 2. Pp. 219-238. 
